\title{
How Historians Play God
}

\section{Citation}

Darnton, Robert. 2003. How historians play God. European Review 11(3): 267-280.

\section{Published Version}

http://dx.doi.org/10.1017/S1062798703000279

\section{Permanent link}

http://nrs.harvard.edu/urn-3:HUL.InstRepos:3415437

\section{Terms of Use}

This article was downloaded from Harvard University's DASH repository, and is made available under the terms and conditions applicable to Other Posted Material, as set forth at http:// nrs.harvard.edu/urn-3:HUL.InstRepos:dash.current.terms-of-use\#LAA

\section{Share Your Story}

The Harvard community has made this article openly available.

Please share how this access benefits you. Submit a story.

\section{Accessibility}




\section{How historians play God}

\section{R OB ERT D A R N T O N}

Department of History, Princeton University, 129 Dickinson Hall, Princeton, New Jersey 08544-1017, USA. E-mail: darnton@princeton.edu

This essay recounts the career of Jacques-Pierre Brissot, the leader of the Girondists during the French Revolution, in a manner designed to pose questions about the nature of historical research in general. How, in piecing together information taken from scraps of paper, do historians come to an understanding of other lives? Put in the abstract, the problem belongs to epistemology or ethics. Confronted in practice, it is more like the puzzles uncovered by archaeologists. The historian digs out a shard of evidence from the archives and asks: was Brissot, the ultimate idealist, a spy for the police? By stepping in and out of layers of time, the historian is actually playing a deeper game, one that he or she may be reluctant to admit.

Hard Facts have gone soft: there is no denying it, no matter where you took a stand during the last few decades while the waves of relativism swept over the intellectual landscape. Historians may still favour metaphors, such as digging in the archives, but who believes in quarrying out nuggets of reality? Words such as 'facts' and 'truth' make us uncomfortable and stir the urge to run for protective covering. If you are writing a biography, begin it with disclaimers. An introduction should surround the subject with a warning: we can never know the 'real' Virginia Woolf or Teddy Roosevelt, and any reader who suspects the writer of unsophistication should be made to enter the book through a discourse on method.

I was recently writing a protective prolegomenon to a biographical study of Jacques-Pierre Brissot, the leader of the Girondists during the French Revolution. Before I deleted it from my screen, I thought back over the 36 years in which I had been tracking this man through the archives. I first came upon him in the Bibliothèque municipale d'Orléans, in 1965. I was the only foreigner who had ever knocked on the library's door, and the man who opened it, a deputy librarian named le Maire, gave me a cordial welcome. He even offered to show me around the city. Because the tour began with the town hall and because my French was too feeble to understand much of it, I decided that M. le Maire must be the mayor of Orléans and I marvelled at the warmth of my reception. Where else, I thought, 
would the respect for research be so great that even a green postgraduate student was given the red-carpet treatment? Only in France. Eventually my command of the language proved strong enough for me to understand that my host was responsible for the city's archives. I began to suspect the reason for his hospitality when he asked me, somewhat tentatively, 'Vous êtes Protestant?' Although I am a devout atheist, my French was not up to a theological confrontation. I opted for simplicity: 'Oui, Monsieur'. 'Nous sommes plusicurs' he answered with a smile. Soon he was pointing out underground shelters where the Huguenots hid from persecution during the reign of Louis XIV. After that, he gave me the key to the library, a skeleton key, which would open everything from the front door to the closets with medieval manuscripts. I would certainly want to work after supper, when the library was closed, and during the weekend - so I could help myself to the documents. A Protestant worked hard. A Protestant could be trusted.

In the archives after dark, I found my first manuscript reference to Jacques-Pierre Brissot. He, too, helped Protestants. He wrote in favour of their emancipation during the 1770s and 1780s, when they were still denied the right to a civil existence - that is, to marry and inherit property. Brissot also agitated against the death penalty and against slavery. He was a passionate Rousseauist, who had actually witnessed an abortive revolution inspired by Rousseau's ideas in Geneva in 1782. His idealism fed his enthusiasm for the American Revolution and all things American, which he celebrated in books and pamphlets, one more radical than the other. In 1787, he founded a Gallo-American Society in company with Etienne Clavière, a Genevan financier and refugee from the revolution of 1782; Hector Saint John de Crèvecoeur, the author of Letters from an American Farmer, which, when transmogrified into Rousseauistic French, had taken Paris by storm; and Nicolas Bergasse, a radical lawyer and notorious Mesmerist. The club did not last long, but it generated enough documentation for me to write a B. Phil. thesis about it at the University of Oxford.

I had tried to follow the ideological currents coursing through Jefferson's Paris. And in 1788, when Brissot left Paris for a tour of the United States, I continued to trail him. His path led back to revolutionary France, where he founded Le Patriote français, one of the most radical newspapers from the new Left in 1789, and helped to found the Société Française des Amis des Noirs, an influential antislavery society, which also functioned as a political club. For me, the trajectory of Brissot's career led through all the best causes of the 18th century and linked the Enlightenment to the Revolution.

It was therefore quite a jolt when I opened a folder in the papers of Jean-Charles-Pierre Lenoir, Lieutenant-general of police in Paris from August 1774 to May 1775 and from June 1776 to August 1785 in the library of Orléans and found this note in Lenoir's hand: 
Brissot remained in Paris [after his release from the Bastille, where he had been imprisoned by lettre de cachet from 12 July to 10 September 1784]. He came to offer his services to the police. I refused them, but for about a year he maintained espionage relations with one of the secretaries in that department who presented his reports to me, and he was paid for those reports. Shortly before my retirement, Brissot was still employed as a spy for the police.

Brissot a police spy? A hard fact? Lenoir included that statement among some notes that he intended to assemble into a draft of his memoirs, which he never completed. He wrote sometime after 1800, when he was living outside France as a refugee from a revolution that he hated. Perhaps he meant to denigrate the Revolution by blackening the name of one of its most eminent leaders. But Lenoir had no personal quarrel with Brissot. None of the other references in his papers betrayed any determination to distort the past. On the contrary, he seemed to be scrupulously accurate, and his contemporaries generally described him as an honest and capable civil servant. One could fudge the issue by noting that 'espionage' might amount to nothing more than writing relatively innocent reports about authors and public opinion. But the Parisians abhorred police spies well before the Revolution. They lynched at least one of them in 1789. And Lenoir used explicit language: Brissot was employed and paid 'as a spy for the police'. Thirty-six years later, I still find myself disturbed by the irreducible either/or quality of the question: either Brissot spied for the police, or he did not; either Lenoir told the truth, or he was lying.

Orléans was the first stop on a research trip that ended in a truly great and virtually untapped archive: the papers of Brissot's publisher, the Société typographique de Neuchâtel (STN) in Switzerland. The STN printed large numbers of pirated and prohibited books, which it smuggled across the Jura Mountains and sold everywhere in France. Similar publishers and wholesalers had sprung up all around France's borders, and they did a huge business, thanks to the restrictions imposed on publishing within the kingdom by censorship, the booksellers' guilds, and the book police. The papers of the STN - 50000 letters and all sorts of account books - are the only ones that have survived from this vast sphere of activity. They include 119 unpublished letters of Brissot, as I had learned by writing to the library of Neuchâtel after coming upon a footnote in a book of local history. The letters were waiting for me when I arrived: 119 letters in a mountain of documents concerning every aspect of the publishing industry from buying paper to selling books. Unable to resist the temptation, I began sampling letters by other authors. To my amazement, I turned up one by a still more famous leader of the French Revolution - Jean-Paul Marat.

Marat was born in the village of Boudry near Neuchâtel and completed his schooling in Neuchâtel's collège before embarking on a career as a doctor and scientist in France and England. The letter, addressed to Frédéric-Samuel 
Ostervald, a family friend and one of the founders of the STN, included a long, cantankerous defence of Marat's most ambitious work, De l'homme, ou des principes et des lois de l'influence de l'âme sur le corps et du corps sur l'âme (Amsterdam, 1775-1776, three volumes). It revealed a great deal about Marat's state of mind and early career. But the most important aspect of it turned out to be its date: 14 May 1776. At that time, according to several of his biographers, Marat was in prison for having stolen $£ 100$ worth of coins and medals from the Ashmolean Museum in Oxford. As the story went, he had been teaching French at Warrington Academy, Lancashire, under an alias, Jean-Pierre Le Maître. He defended himself eloquently at his trial, perhaps by invoking the principle proclaimed in his Plan de législation criminelle: 'Whoever steals in order to live, when he cannot do otherwise, only makes use of his rights'. This Le Maître then escaped from prison in time to reappear in Paris as Marat, whose existence as doctor to the gardes du corps du comte d'Artois can be documented from June 1777. The story had enough plausibility and more than enough fascination to touch off polemics that stretch back to an article in the Glasgow Star of 4 March 1793. But it was wrong. The letter I held in my hand was written from France before the jailbreak in England. The whole debate turned on a case of mistaken identity.

Without meaning to, I had declared Brissot guilty, or at least probably guilty, of spying and Marat innocent of theft. I was pronouncing a verdict about two individuals whom I had never met and who could not defend themselves, because they had died in a far-off revolution 200 years ago. Was this a proper exercise of the historian's vocation?

Back to Brissot. Now that I have recently published all those letters along with a biographical essay ('J.-P. Brissot and the Société typographique de Neuchâtel, 1779-1787', Voltaire Foundation Electronic Text Centre), I realize that I have never stopped living with the man since 1968, when I decided to abandon a full-scale biography of him. I gave up that project because I considered it more important to undertake another one: the history of books, a new kind of subject, which emerged from exposure to the archives in Neuchâtel. A 500-page draft of a life of Brissot lies in the bottom of a drawer in my office. Should I try to breathe new life into it, or have I spent so much of my own life chasing other hares that I could never catch his scent again? Is he worth the trouble? Does he really matter?

Most historians probably would come up with two arguments for the importance of studying Brissot. First, of course, he was one of the dozen most prominent leaders of the French Revolution: the more we know about him, the better. He was identified with the 'Brissotin' or Girondist phase of the Revolution, the last period of moderation before the onset of the Terror. He and his allies were republicans, idealists, radicals in their way, but not men of blood. They can be romanticized, as in Lamartine's Histoire des Girondins, but they cannot be dismissed as trivial. Quite the opposite: they stood for the highest principles, and 
most of them, Brissot included, went bravely to the guillotine. In a half dozen biographies, Brissot appears as the epitome of idealism in action. The most recent of them, published last year by Leonore Loft, compares him to Nelson Mandela.

Second, Brissot appears in the biographies and in general works on the 18th century as the incarnation of a crucial process, the transition from Enlightenment to Revolution. The connection between those two phenomena often looks problematic, but Brissot wrote Enlightenment tracts before 1789 and championed Enlightenment causes afterward. Daniel Mornet, the greatest authority on the intellectual origins of the French Revolution, described him as 'the perfect image of all the aspirations of a generation'. Whoever can find the key to Brissot's life may be able to unlock the most important problems of his times - not to resolve them definitively, of course, but to show how a representative individual lived through them and incorporated them in the basic pattern of his life.

The letters in Neuchâtel certainly open up a new perspective on the life of Brissot, because they show bow an obscure provincial youth tried to succeed in a career as an author. Brissot had no protectors or connections of any importance, so he had to write his way into the Republic of Letters. His father, a fairly wealthy caterer ('maître cuisinier et traiteur') in Chartres, wanted him to be a lawyer. But while completing his secondary education, Jacques-Pierre fell under the spell of Voltaire; and while clerking for attorneys, first in Chartres, then in Paris, he took to writing essays on subjects such as the absurdities in the epistles of Saint Paul and the iniquities in France's system of criminal law. His father, reinforced in his stern Catholic faith by priests from the cathedral, threatened to disinherit him, and finally left him only 4000 livres, a minimal 'légitime', from a fortune of more than 100000 livres, when he died in 1779. Jacques-Pierre used some of the money, 600 livres, to buy a perfunctory law degree from the University of Reims but soon abandoned the law for literature. He explained in his Mémoires: 'Henceforth free, I resolved to devote myself entirely to the profession of writing.'

Was writing a profession at that time? This question occupies a central place in the sociology of literature as developed by Robert Escarpit, Pierre Bourdieu and Alan Viala. Brissot's memoirs reveal something of the strategy he pursued in order to get ahead in his career. He appealed for help to Voltaire and d'Alembert, competed in prize essay contests after the example of Rousseau, cultivated contacts in literary circles, and wrote one philosophical treatise after another. Although he failed to break into the front ranks of the philosophes, he attracted enough attention to be persecuted by the state. He escaped from the first lettre de cachet issued for his arrest in 1777 , but the second led to his imprisonment in the Bastille for two months in 1784. A Bastille record on top of a bibliography of Enlightenment tracts provided him with a perfect pedigree in 1789, when he emerged as a prototypical philosophe turned revolutionary.

Brissot cast himself in this role when he described his pre-Revolutionary career 
in his memoirs, and his biographers have followed suit. I did, too, when I started reading his dossier in the papers of the STN in 1965. In some ways, the new material confirmed the old picture from the memoirs. It showed how Brissot published most of his books. Too obscure and too outspoken to sell his copy to publishers in France, he paid the Swiss to print it and hoped to cover his costs by marketing the editions through middlemen in France's vast underground book trade. His most ambitious book, Théorie des lois criminelles (1781), certainly deserves a place among the legal treatises of the Enlightenment, although it is derived almost entirely from the more original work of Cesare Beccaria. It impressed the STN's principal director, FrédéricSamuel Ostervald, who took a somewhat fatherly interest in Brissot. The two met when Ostervald made a business trip to Paris in 1780, and they seemed to hit it off. By 1781, Brissot's correspondence with Ostervald took on a confidential tone, and his confidences concerned his efforts to win fame and fortune as a writer.

Of course, the best of writers may confess at times to extravagant ambition and describe their careers as moves in a game of getting ahead. But I was surprised to find the theme of self-advancement so pervasive in Brissot's letters. They show him seeking introductions, cultivating endorsements, trying to get his name in journals, soliciting reviews, demanding special treatment in essay contests, and manoeuvring to get elected to academies. In his memoirs he claimed that he scorned academies because of their exclusiveness, but in his letters he asks Ostervald to promote him in the STN's Journal helvétique as 'M. Brissot de Warville, lawyer at the Parlement of Paris, member of diverse academies, already known by his Théorie des lois criminelles of which we have spoken in our earlier issues and by a memoir on the same subject crowned last year at the Académie de Châlons'. He also claimed in his memoirs that he had always hated kings, but he directed Ostervald to send specially bound copies of his books to Frederick II and Catherine IL: 'I am making my debut in literature, and my name is not at all known. ... As I want this work to cause a sensation, it must have the most publicity possible, it must be sent out everywhere, to all the crowned heads, and I will spare nothing to that end'. After sketching a plan for a treatise on 'universal pyrrhonism', Brissot begged d'Alembert to write him a letter that would serve as a preface to it. But when d'Alembert sent only two tepid lines, he abandoned the plan. His connections with the Courrier de l'Europe, where he had worked for a while as a proof-reader, provided him with some publicity; but he raged at his inability to crack the Journal de Paris. He got himself elected to the Académie de Châlons-sur-Marne, but he found it impossible in Paris to advance beyond the Musée of Pilâtre de Rozier, a non-exclusive literary club where anyone could read a paper on anything. He got nowhere with the Société économique de Berne, despite endless lobbying for favour in its prize essay competition. And none of 
his books produced the slightest splash, although he tried hard to orchestrate favourable reviews.

Brissot's endless stream of proposals to the publisher also suggests self-promotion and entrepreneurship rather than dedication to Enlightenment. He seemed eager to write on almost anything: a ten-volume digest of the proceedings of the Académie des inscriptions et belles-lettres, a ten-volume biographical dictionary of men of letters, a compilation of works on education, a treatise on how to learn languages, a history of criminal law. All of these works sounded like pot-boilers, and none of them ever made it into print, because Brissot wanted to sell them to the STN. In proposing the anthology of writings from the Académie des inscriptions et belles-lettres, he explained that he would churn out copy by recruiting hacks: 'I will direct a group of subaltern labourers'. Brissot actually speculated on two compilations of his own, a ten-volume Bibliothèque philosophique du législateur (1782-1785) and a Correspondance universelle sur ce qui intéresse le bonheur de l'homme et de la société (1783) that was supposed to go on indefinitely but stalled after volume 2 . Their titles suggest high-mindedness, but their contents show them to be nothing more than scissors-and-paste jobs. In fact, Brissot never wrote anything of any distinction - at least not as far as I could tell after ploughing through thousands of pages of his prose. His most important work, Théorie des lois criminelles, was, as mentioned, little more than a pastiche of Beccaria's Dei delitti et delle pene, and his most pretentious publication, De la vérité, ou méditations sur les moyens de parvenir à la vérité dans toutes les connaissances humaines (1782), merely rehashed the standard commonplaces of Enlightenment thought.

The only works by Brissot that attracted any attention from his contemporaries were pamphlets, and insofar as they made him known at all, they gave him a reputation as a vehement polemicist. After reading his Le Philadelphien à Genève (1783), Jacques Mallet du Pan described him as an example of the most vulgar element in literature: 'Men of letters these days are becoming riffraff ['canaille'], and the vilest kind of riffraff, because they combine impudence with cowardice.' Brissot's violent pamphlet against F.-J. de Chastellux's Examen critique des Voyages dans l'Amerique septentrionale de M. le marquis de Chastellux (1786) caused Jean François de La Harpe to deride him as 'one of those affected madmen, the extravagant souls who have made themselves into the monkeys of Jean-Jacques Rousseau and who, by repeating words like virtue and humanity over and over again, think they are as eloquent as he was'. Those judgements may say more about their authors than about Brissot, but a more neutral assessment by Friedrich von Freudenreich, the secretary of the Société économique de Berne, seemed to take his measure pretty accurately. In a letter to Ostervald explaining that the Société économique would not bend its rules, as Brissot had requested, in order to give him an inside track in a prize competition, Freudenreich observed: 
At his age [then twenty-eight], to put himself forward as a totally competent judge of all aspects of philosophy, politics, and law, to present himself as a new Archimedes ... is to exhibit a degree of self-importance of which only a young French man of letters is capable.

For my part, I think that if Brissot is to be taken seriously as a philosophe, he represents the High Enlightenment at middle brow. But why consider him as a philosopher at all? Because he presented himself that way in his memoirs and because his biographers modelled their interpretations on his. He appears in a different light, however, when seen through his correspondence with the STN. In addition to proposing pot-boilers that never got published, he published pamphlets that never were attributed to him - because they were anonymous. The STN printed four of them, all unknown to his previous biographers. One was an amateurish essay about studying languages, one a polemical account of the literary scene in Paris, and two were tendentious broadsides about international relations. When I read the latter, I thought I recognized the Brissot of 1792. Instead of discussing issues seriously, they heaped abuse on France's enemies and struck a vituperative tone, which sounded something like his speeches to the Jacobin Club a decade later, when he did more than anyone else to embroil the Revolution in a disastrous war. In short, when the corpus of Brissot's works is viewed through the archives of his publisher, it does not appear very philosophical; and Brissot himself does not look like much of a philosopher.

Perhaps, however, I have been infected by the bias of Brissot's enemies. I must admit that once I began to read his works against the grain, they lost their lustre, and after I pieced together the story behind their publication, they smelled bad. A biographer should beware when he starts to dislike his subject. But once I started, I could not stop. Every bit of evidence that I turned up reinforced my tendency to suspect the man projected in the memoirs, especially when I investigated the financial side of his ventures into literature.

Brissot's inheritance sufficed to pay for the printing of his first books. But when it gave out, he adopted a strategy of pyramiding: the sales of one book were to pay for the cost of producing another. It was possible to postpone the reckoning from one publication to the next because of the delays built into the system of payment. Like most authors who commissioned books with the STN, Brissot promised to cover their cost with bills of exchange that matured six months after he received the printed copies. If he could market them fast enough, he could square his accounts. He wrote the bills on his Parisian bookseller, E.-M.-P. Desauges, a wily veteran of the underground, who collaborated with equally shady characters, such as Jacques Revol, a smuggler in Lyons, and the Widow La Noue, a shipping agent with secret stockrooms scattered through Versailles. The middlemen had enough expertise to handle their roles effectively; but, as Brissot described them in his letters, they operated on the principle of honour among 
thieves, and they had no honour. In the end, after all sorts of complications and manoeuvres, Desauges refused to accept Brissot's bills of exchange, and Brissot protested that he had been fleeced by a pack of rogues.

He also had another excuse for failing to pay his bills: the police had confiscated a shipment of five hundred copies of his Théorie des lois criminelles. Therefore, in his version of his difficulties, he was an innocent who had fallen victim to enemies on both sides in the battles of the books - the agents of royal despotism on the one hand and their adversaries from the literary underground on the other. In fact, however, the situation was more complicated than he admitted. The underground actually performed its tasks quite well. The shipment of Théories made it to Widow La Noue's warehouse without a hitch, but Brissot thought he could get it past the inspectors in Paris by having it shipped directly to the headquarters of Lenoir, the lieutenant general of police. Why did he take such an audacious step? He was confident, he explained to the STN, that the police had given him 'a secret permission for passage into Paris'. But Brissot must have misunderstood some message from police headquarters. Instead of turning the books over to Desauges, Lenoir sent them to Le Camus de Néville, the inspector of the book trade, and Néville promptly confiscated them.

After months of negotiation, Néville finally permitted Desauges to sell 100 copies under the counter and agreed to ship the other 400 back to the STN, which eventually sent them back again to Desauges by a still safer route. By then they had accumulated so much in shipping charges that Desauges reaffirmed his refusal to pay the bill of exchange. Meanwhile, Brissot had received clearance from the police to ship his Bibliothèque philosophique into Paris. His contact seems to have been Lenoir's secretary, named Martin, who supervised the policing of the illegal book trade, because in reassuring the STN that the police would not interfere with the shipments, Brissot explained: 'M. Martin, who seems to hold me in esteem and to be attached to me, assured me of his zeal.' The first shipments made it safely, as promised, to Desauges's shop behind the Palais de Justice. But then Brissot overplayed his hand. He printed the prospectus for his Correspondance universelle in volume 5 of the Bibliothèque philosophique without getting permission from the police. To circulate an illegal prospectus was a serious offence, so the police confiscated the shipment of volume 5, making it impossible to sell the entire ten-volume set and throwing Brissot's finances into disarray. I concluded that Brissot had indeed suffered from the repressive apparatus of the Old Regime - not, however, because he defied the police, but because he botched his arrangements to collaborate with them. The full extent of Brissot's indebtedness is a complicated story that involves his attempt to create a lycée, or literary club, in London, which he modelled on the Musée of Pilâtre de Rozier in Paris. It went broke, he went bankrupt, and after a brief stay in a London debtor's prison just after his wife gave birth to their first child, he returned to Paris in order 
to find a financial backer. His main hope was the friend he had made during the troubles in Geneva, Etienne Clavière. But on 12 July 1784, after he had spent an evening discussing his predicament with Clavière, the police carried him off to the Bastille. I calculate his debt at that point as 25636 livres - the equivalent of 80 years of wages for an ordinary labourer.

Why did the police imprison Brissot? Not, as he said in his memoirs, because of his radical philosophizing but, as the Bastille records put it, 'pour libelles' that is, for libel. In fact, his first brush with the police in 1777 , when he had narrowly escaped the Bastille, had also been for libel, because, in a pamphlet entitled Le Pot-pourri, he had made some nasty remarks about lawyers, men of letters, and the morals of a lady who kept a salon. His offence in 1784 was far more serious, because the pamphlets attributed to him concerned the sex life of the queen. Brissot had spent much of 1783 and 1784 in a colony of French expatriates in London, who supported themselves by libelling and blackmailing the leading figures of the French court. They were a rum lot defrocked priests, déclassé noblemen, Grub Street writers - and one of their most cynical slanderers was a marquis turned adventurer named Anne Gédéon Lafitte de Pelleport. In his memoirs, Brissot claimed that he hardly knew Pelleport and did not meet him until 1783. But the first of his letters in the STN archives, dated 31 August 1779, is addressed to Pelleport, who was then in Neuchâtel; and by 18 th-century standards, it is extremely intimate in tone: 'Addio il mio caro. Je vous embrasse ...'

Having lured Pelleport back to France, the police arrested him on the day before they captured Brissot. It seems likely that he implicated Brissot and that Brissot returned the favour during his own interrogations. According to his memoirs and other writings, the police tortured him by shutting him up in an underground cell and cutting him off from all contact with the outside world, including his wife. According to the archives of the Bastille, Brissot was treated well, allowed to walk in the Bastille garden, and saw his wife several times, beginning on 'the 24th [of August], from 9:30 to 10:30'.

Did Brissot collaborate on smutty pamphlets like Les Amours de Charlot et Toinette, Le Passe-temps d'Antoinette et du vizir de Vergennes, La Naissance du dauphin dévoilée and Le Diable dans un bénitier? Having read through the elaborate reports by French agents in London that are scattered through the archives at the Quai d'Orsay, I think it unlikely. None of the spies linked a specific libel to Brissot, and the police released him after only two months, whereas they kept Pelleport behind bars for four years. But as two of his friends hinted in letters to the STN, Brissot might have helped distribute some of the pamphlets. And after finding himself betrayed, he may have told the police everything he knew about Pelleport and the other London libellistes. We cannot verify those hypotheses, however, because Brissot's dossier has disappeared from the archives of the 
Bastille. It was given to him after 14 July 1789 by his friend Pierre Manuel and never seen again.

The ambiguities surrounding Brissot's embastillement bear on the question that has been gnawing at me all these years: was Brissot a police spy? He mentioned confidential contacts with the police several times in letters to the STN before his imprisonment, and in a letter written afterward, on 19 February 1785, the STN's agent in Paris, J.-F. Bornand, reported that Brissot had been meeting with ' $M$. Martin, first secretary of the lieutenant general of police' and that Martin had provided him with some inside information about police measures against book smuggling. Martin could have been the secretary mentioned in Lenoir's statement about Brissot's spying. And Lenoir's statement fits the picture of growing desperation that emerges from Brissot's correspondence with the STN. It also fits the way Brissot was pictured at that time by Marat:

There he was [after his release from the Bastille] in the street, without any resources, and to add to his misery, burdened with a wife and a baby. It is now notorious that, not knowing what to do, he decided to offer his services to Lenoir, the lieutenant of police, who made him a royal observer for 50 écus [150 livres] a month.

Although Marat and Brissot became mortal enemies after 1790, they were intimate friends in the 1780s. And Marat's account of Brissot's spying correlates closely with that of Lenoir. But it, too, should be read with scepticism, because it appeared in Marat's Ami du peuple on 4 June 1792 at a moment when he was capable of saying anything. The same accusation, with plenty of inconsistencies and inaccuracies, can be found in a dozen attacks on Brissot by his enemies during the nastiest episodes of political dogfighting from the beginning of the Revolution right up to his trial before the Revolutionary Tribunal, when it led the items on his indictment. Considering the viciousness of the polemics and the tragedy of the outcome, one can only conclude that the case against him remains unproven.

I admit, however, that I believe Brissot was probably a spy. This conviction grew as I read through his letters in Neuchâtel. By 1784, the theme of frustrated ambition turned into financial desperation, and in the first letter that he wrote to the STN after his release from the Bastille, he confessed that he was ruined. A salary of 150 livres a month from the police could have supported his family, but a lifetime of labour would not have sufficed to pay off the debts that he owed in London and in Neuchâtel. Ultimately, he was rescued by Etienne Clavière, who not only gave him loans but also persuaded the STN to take back his books in lieu of payment for their printing.

The full story of Brissot's attempts to crawl out of bankruptcy between 1784 and 1789 involves a great deal of arithmetic. In order to make sense of it, I found myself working over Clavière's account books in the Archives Nationales in Paris. 
They had been confiscated by the revolutionary police after the Convention decreed the arrest of Clavière along with the other Girondists, and they reveal an impressive series of payments to Brissot during the second half of the 1780s, along with credits for services rendered. Brissot had originally obliged Clavière by writing Le Philadelphien à Genève, a pamphlet that defended Clavière and his faction in the failed Genevan revolution of 1782. After that failure, Clavière emigrated to Paris and devoted himself to speculations on the Bourse. As a leader of a group of bears, he bet on futures, and to win his bets, he commissioned pamphlets that exposed manoeuvres by the bulls to artificially inflate the value of the shares. Brissot wrote most of the pamphlets, sometimes with other hacks under the name of Mirabeau, sometimes anonymously or under his own name, when the bear propaganda turned into a campaign to unseat the controller general of finance and to prevent the king from declaring bankruptcy.

Brissot's pamphleteering for Clavière took him directly into the struggles that brought down the Old Regime, but when the rickety edifice began to fall, he was in America - in order to investigate republicanism first hand, according to his memoirs. Back in America myself I picked up Brissot's trail in the American Antiquarian Society, the Massachusetts Historical Society, and the New York Historical Society. Those archives showed that he had been using Clavière's money to speculate on the paper currency of the colonies, which could be worth a fortune if redeemed at anything near their face value by the new federal government. There was nothing illegal about these transactions, although they involved some dubious characters such as William Duer and Christopher Gore. There was no reason to doubt the authenticity of Brissot's enthusiasm for all things American, money included. Brissot even considered emigrating, but word of the coming Revolution drew him back to France. He founded Le Patriote français three months before the Bastille fell, and his fortune rose with the success of his newspaper. For a few moments in the spring of 1792 , he probably was the most powerful man in France. He used his power to have Clavière appointed minister of finances. The Revolution was their greatest speculation, and they went down together in the spring of 1793.

Put that baldly, Brissot's biography looks like a string of lies, the very opposite of the narrative line developed in his memoirs and adopted by all of his biographers, except me. Propelled by the sensation of belonging to a minority of one and by the eternal temptation of revisionism, I enlisted in a faculty seminar on psycho-biography that was being taught at Harvard in 1967 by Erik Erikson. I gave a paper on Brissot and began by announcing, with some exaggeration, that I could find a lie on every page in Brissot's memoirs. Erikson interrupted: 'In psychoanalysis,' he said, 'we do not speak of lies; we speak of screen memory'.

I reworked the paper, purged of references to the Oedipal complex and the stages of infant sexuality, as an article published in the following year: 'The Grub 
Street Style of Revolution: J.-P Brissot, Police Spy'. Rereading it today, I see a lot of anger in it, a lot of 1968, and even of my own biography. I now feel less hostility to Erikson, surrounded as he was by an unfortunate cult of personality, and I feel more sympathy for the notion of screen memory.

How much screening have I been guilty of? I use the word 'guilt' because I cannot help but ask what Brissot, poor bastard, ever did to me? Something happened after that first encounter with the manuscripts of Lenoir. The facts seemed hard enough, but I kept arranging them in darker patterns. From literary ambition to hack writing, indebtedness, bankruptcy, spying, speculating, jobbing his protector into power, and pushing France into disasters abroad and at home, Brissot turned into the antithesis of the man I had once admired. Can biography get caught in gestalt switching?

The facts have not dissolved into discourse, but they now look different. I now think that Brissot really was an idealist, a true believer in Enlightenment, and when he lied, he believed in his lies. They were authentic, like the tricks of memory in the Confessions of Rousseau. Brissot wrote his memoirs in prison, in the shadow of the guillotine, after reading the Confessions for the sixth time. The memoirs lack the ring of genius, but they do not ring false. They are the authentic memoirs of a Grub Street hack caught up in a revolution that was partly of his making. God rest his soul. God have mercy on all of us.

You may suspect me of losing my grip on facts and of slipping into postmodernism, or even the sort of superstition that the Enlightenment combated. So let me cite a final fact, which I dug out of the same archives in Neuchâtel: the death of Jean-Elie Bertrand on 24 February 1779.

Bertrand was a Protestant pastor turned man of letters. After marrying Ostervald's daughter, he became one of three directors of the STN. Judging from his letters, the letters of his friends, and two volumes of his sermons, he was a sympathetic character - a good husband and father, generous, cultivated, open-minded, and committed to the moderate, Swiss variety, of Enlightenment. He died at age 40, leaving a widow and three children. That loss forever marked their lives, as you can see by following its effects through letters from the family. Other letters, mostly about business, also lead to Bertrand's dossier. These kept carrying me back to it, when I was tracing other stories through other dossiers. And every time I opened the dossier of Bertrand, I knew what would happen.

At one point, he assures a correspondent that his cough is getting better. At another, he cannot make a meeting, because he is bedridden. Then things brighten up: he has been back in the printing shop. But the awful, inevitable day is only a few letters away: 24 February, Bertrand is gone forever.

I can replay the dying of Bertrand in many ways, stop it at any point, run it 
backward or fast-forward it to links with letters that relate to his in endless combinations.

What am I doing? What every historian does: playing God. As Saint Augustine explained, God exists outside time. He can replay history as He pleases, backward or forward or all at once.

The historian certainly creates life. He breathes life into the mud that he digs out of the archives. He also passes judgement on the dead. He cannot do otherwise: either Brissot spied for the police, or he did not. The facts will not go away, but their pattern changes as I rearrange them, not merely by whatever artistry I can summon up, but by gestalt switches: revolutionary or police spy, philosopher or literary hack, rabbit or duck? Perhaps, however, the either/or approach to biography is flawed. Perhaps life is a bundle of contradictions, and the attempt to impose consistency on it is wrong. Was Brissot both a dedicated revolutionary and a crass spy for the police? God only knows. The historian knows, but imperfectly, through documents darkly, with help from hubris, by playing God.

\section{About the Author}

Robert Darnton is Shelby Cullom Davis Professor of European History at Princeton University and was formerly Director of the Program in European Cultural Studies at Princeton. He was a Rhodes Scholar at Oxford 1960-64 and a Fellow at the Netherlands Institute for Advanced Study 1976-77. Among his books are Mesmerism and the End of the Enlightenment in France, 1968; The Business of Enlightenment: A Publishing History of the Encyclopédie, 1979; The Literary Underground of the Old Regime, 1982; The Great Cat Massacre and Other Episodes in French Cultural History, 1984; The Kiss of Lamourette: Reflections in Cultural History, 1989; Berlin Journal, 1989-1990, 1991; The Forbidden Best-Sellers of Prerevolutionary France, 1995; and George Washington's False Teeth: An Unconventional Guide to the Eighteenth Century, 2003. 